\title{
POLISH ACADEMY OF SCIENCES
}

\section{MUSEUM \& INSTITUTE OF ZOOLOGY}

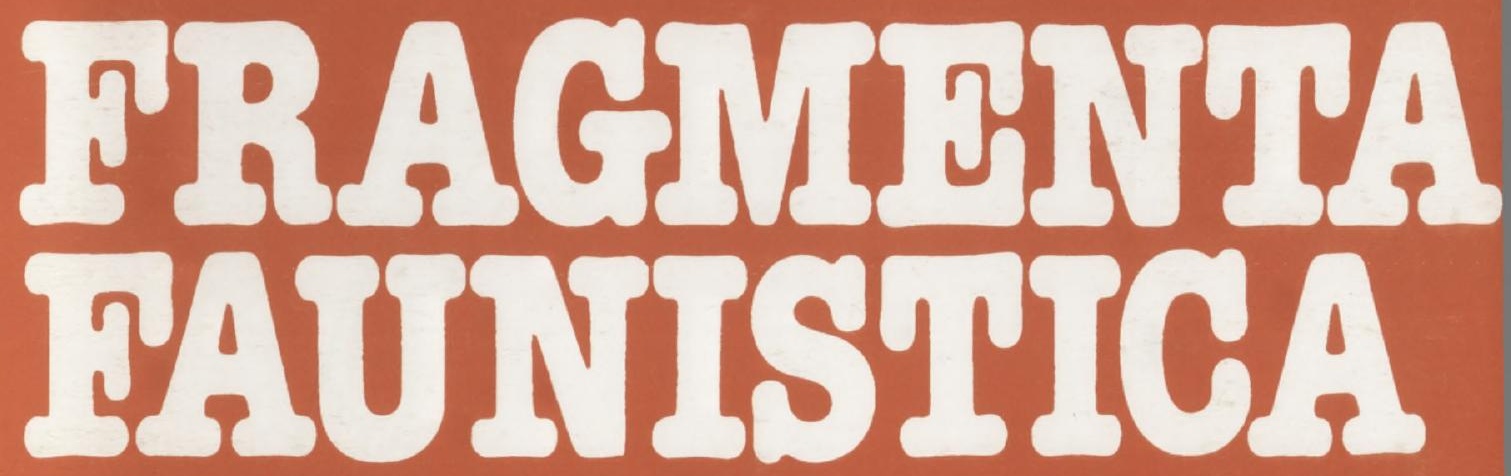

Vol. 42 , No. 1-6 


\section{FRAGMENTA FAUNISTICA \\ An International Journal of Faunology \\ Warsaw}

FRAGMENTA FAUNISTICA is a specialist journal published by the Museum and Institute of Zoology of the Polish Academy of Sciences. The journal, first published in 1930, appeared under the title Fragmenta Faunistica Musei Zoologici Polonici until 1953. Now the journal is issued as a semi-annual and publishes the papers devoted to knowing fauna, its differentiation, distribution and transformation. These are the results of oryginal studies, review articles and syntheses dealing with faunology and related sciences as zoogeography or zoocenology.

By way of exchange, FRAGIMENTA FAUNISTICA is sent to over 350 institutions in 80 countries. It has been cited in the Zoological Record, Biological Abstracts, Biosis, Pascal Thiema and Referativnyj Zhurnal and indexed by Polish Scientific Journal Contents - AGRIC.\&BIOL.SCI. available through INTERNET under WWW address: http://saturn.ci.uw.edu.pl/psjc

\section{Editorial Office:}

Muzeum i Instytut Zoologii Polskiej Akademii Nauk (Museum and Institute of Zoology, Polish Academy of Sciences) Wilcza 64, 00-679 Warszawa

Editor-in Chief: Prof. Dr. Regina Pisarska

Editorial Secretary: Dr. Jolanta Wytwer

Editorial Board: Dr. Elżbieta Chudzicka, Dr. Waldemar Mikołajczyk, Dr. Irmina Pomianowska-Pilipiuk, Dr. Ewa Skibińska, Dr. Maria Sterzyńska

\begin{tabular}{|c|c|}
\hline \multicolumn{2}{|c|}{ Advisory Board: } \\
\hline Prof. Dr. Józef Banaszak (Bydgoszcz) & Prof. Dr. Sędzimir Klimaszewski (Katowice) \\
\hline Prof. Dr. Czesław Błaszak (Poznań) & Prof. Dr. Andrzej Leśniak (Kielce) \\
\hline Dr. Wiesław Bogdanowicz (Warszawa) & Prof. Dr. Wojciech Niedbała (Poznań) \\
\hline Dr. Thomas Bolger (Dublin) & Dr. Bogusław Petryszak (Kraków) \\
\hline \begin{tabular}{|l} 
Prof. Dr. Michał Brzeskil(Skierniewice) \\
\end{tabular} & Prof. Dr. Adolf Riedel (Warszawa) \\
\hline Prof. Dr. Jarosław Buszko (Toruń) & Dr. Josef Rusek (České Budějovice) \\
\hline Dr. R. Henry L. Disney (Cambridge) & Prof. Dr. Wojciech Staręga (Białystok) \\
\hline Prof. Dr. Reiner Ehrnsberger (Vechta) & Prof. Dr. Andrzej Szeptycki (Kraków) \\
\hline Prof. Dr. Charles Gaspar (Gembloux) & Prof. Dr. Przemysław Trojan (Warszawa) \\
\hline
\end{tabular}

(C) Copyright by Museum and Institute of Zoology, PAS ISSN 0015-9301

Printed in Poland: Drukarnia ARKUSZ-DRUK, Czarnocińska 10, 03-110 Warszawa 


\section{INSTRUCTIONS TO AUTHORS}

Only papers written only in English (preferred language), German or French are published in FRAGMENTA FAUNISTICA. A paper submitted to the FRAGMENTA FAUNISTICA must not have been offered, previously or simultaneously to any other scientific magazine. Although the author bears responsibility for the merits of the paper, the editors reserve the right to suggest alterations and abridgements. Papers should be concise and linguistically correct. Contributions should be submitted in two copies, complete with the text, tables and figures. The relevant letter from Author(s) accompanying the manuscript is required, where the author(s) address(es) for correspondence is placed, with the original and officially accepted name of institution(s), number of fax, phone or e-mail address.

Submitted papers will be accepted for publication after positive reviews have been obtained, mainly from the members of the Fragmenta faunistica Advisory Board. The final version of the work, after the verification made by reviewers' and editor's advice, should be submitted as a printout and on a computer disk (MS-DOS/Windows), and must conform to the requirements below.

Title of work should be concise and proper to its contents. Abstract shouldn't be longer than 200 words. Key words must be in number 3 to 7 . Text should have a standard layout (introduction, material and methods, results, summary, references). All Latin names must be italicised. The names of authors must be added to all species (genus) names first appearing in the text. Tables should be as simple as possible, printed on separate pages with captions and numbered with Roman numerals. Figures identified with Arabic numerals, can be computer printouts ( $\mathrm{B} \& \mathrm{~W}$, good quality) or made by hand in black ink on tracing paper or white cardboard, with all captions printed on a separate page. Numerical data should be attached to plots. References should conform to the format used in published issues of FRAGMENTA FAUNISTICA.

Printing costs are covered by the author. Information about the cost is available from the Editorial Board. The author (first person listed) will receive 25 copies free of charge.

Subscriptions and orders should be adressed to the Museum \& Institute of Zoology, PAS, Library. Wilcza 64, 00-679 Warszawa. Annual subscription ( 2 issues): 60 USD. Orders paid on the account on the Museum \& Institute of Zoology at:

Powszechny Bank Kredytowy SA, XIII O/Warszawa,

No. $11101053-3450-2700-37$,

Krucza 24/26, 00-950 Warszawa, Poland 
Fragm. faun. 42: 1999, 1-6.

Contents

No. 1. Wojciech Czechowski, Wieslawa Czechowska. New sites in Poland and notes on the biology of socially parasitic ants Formicoxenus nitidulus (NYL.) and Harpagoxenus sublaevis (NYL.) (Hymenoptera, Formicidae)

No. 2. Wojciech Czechowski, Wiesława Czechowska. New data on the occurrence of ants of the subfamily Ponerinae (Hymenoptera. Formicidae) in Poland

No. 3. Regina Bańkowska. Syrphid flies (Diptera, Syrphidae) from China collected by Polish expeditions

No. 4. Regina Bańkowska. Syrphid flies (Diptera, Syrphidae) from North Korea collected by Polish expeditions. Part II (Syrphinae)

No. 5. Pawel Szymkowiak, Marek Woźny, Monika Błażejczyk. A comparison of the species composition of spider communities over sixty years in the vicinity of Krotoszyn

No. 6. Piotr Skubała, Mariola Ciosk. Oribatid mites (Acari, Oribatida) colonizing the zinc metallurgic dump 